\title{
Return International Migration and Geographical Inequality: The Case of Egypt
}

\author{
Barry McCormick and Jackline Wahba \\ University of Southampton, UK
}

August 2002

\begin{abstract}
This paper explores entrepreneurship amongst return migrants, how their locations and business characteristics differ from other businesses, and the implications for geographical inequality. First, we examine, amongst returnees, the determinants of investment in a project/enterprise. Secondly, we study the impact of return migration on the characteristics and nature of non-farm small enterprises using a sample of return migrants and non-migrant owners of enterprises. Our data indicate that although the share of return migrants originating in urban areas is almost equal to those from rural areas, and that migrants tend to return to their origin region, urban areas benefit more than rural areas from international savings. The empirical evidence also suggests that overseas savings, and the duration of stay overseas, have positive separate effects on the probability of investing in a project/enterprise amongst returnees. Furthermore, returnees from urban-origin are more likely than rural ones to invest in a non-farm enterprise. The empirical results also indicate that return migrants invest more capital in their businesses- given age, education and region- than other owners. However, we find that there is a regional bias in the location of firms and jobs created by returnees compared to non-migrants, in favour of the capital city.
\end{abstract}

\footnotetext{
${ }^{1}$ Dept. of Economics, University of Southampton, Southampton, SO17 1BJ, United Kingdom. Fax: +44 2380593858 , E-mail: $\underline{\text { bmc@soton.ac.uk, j.wahba@soton.ac.uk }}$
} 


\section{Introduction}

Although there has been a considerable interest in the impact of international migration on both home and host countries, the consequences of return international migration is still underresearched. Theoretical studies show that emigration is welfare improving for the origin country if accompanied by enough remittances, Djajic (1986), although the laissez-faire level of migration may not be welfare maximizing if remittances per migrant exceed the origin country wage and there exits a non-traded goods sector- McCormick and Wahba (2000). Empirical analysis of the impact of remittances has been undertaken by numerous authors - for example, Lucas and Stark (1985), Adams (1991), (1998), Lucas (1985), Taylor and Adelman (1996,) Adelman, Taylor and Vogel (1988). A number of studies have focused on the impact of international remittances on inequality in recipient rural areas, but with mixed results. Adams (1989) finds a worsening in the income distribution in rural Egypt as a result of international remittances. A study based on data from villages in northern Mexico indicates that remittances from the U.S. are an equalizing factor in the villages' economies (Stark, Taylor and Yitzhaki, 1986). Another study for rural Pakistan (Adams, 1992) shows that remittances have a neutral impact on income distribution.

However, there have been very few studies of the impact of return migration other than that of the effects of remittances on the home country- see Rapoport and Docquier (2002) for a comprehensive survey of both the theoretical and empirical analysis of the determinants and impact of remittances. Return migration can, however, affect the economic prospects of the origin countries through at least two main channels. First, emigrants may accumulate savings while overseas, that given the low wages and capital market distortions prevailing in many LDCs, might not have been possible without migrating. Secondly, overseas work may enable emigrants to acquire new skills and/or enhance human capital accumulation. Both channels can provide crucial inputs to start a business, or otherwise enhance earnings, on return. Thus, special attention should be given to return migration because it represents an inflow of both financial and human resources. Return migrants are potentially carriers of capital, technology and entrepreneurship, i.e. of factors that can contribute to the economic development of the home country. Insightful overviews of return migration and its development potential are given by Thomas-Hope (1999) for Jamaica, Diatta and Mbow (1999) for Senegal, and Rodriguez and Horton (1995) for the Philippines. 
The aim of this paper is to study the effect of return migration and savings on investment, enterprise development, and employment generation in the home country, and differentiate that effect on rural and urban areas. This in turn may provide empirical insights that will fuel further theoretical analysis of the international migration decision. In particular, we study for Egypt -where about $20 \%$ of the labour force has worked overseas- two important issues. First, we examine, amongst returnees, the determinants of investment in a project/enterprise. We explore the impact of the spatial origin of return migrants, the use of skills acquired overseas, and overseas savings and work experience, on the probability of returnees investing in business ventures in rural and urban areas. Secondly, we study the impact of return migration on the characteristics and nature of enterprises using a sample of return migrants and non-migrant owners of non-farm enterprises. We test whether an enterprise that belongs to a return migrant is more likely to be located in the capital city and to have more formal status. We also test whether there is a positive relationship between the value of capital invested and return migration. This paper is the first to study the enterprises of returnees and non-migrants in urban and rural areas using national level data.

The small theoretical literature on return migration generally examines the phenomena as part of life-cycle strategy. In this framework, return migration is part of optimal decision-making and is related to savings behaviour of migrants, their investment in human capital acquisition whilst overseas and the relative wage differences between the host and home country. One reason for return migration is that the marginal utility of consumption is higher in the home country than in the host country-Galor and Stark (1991). Another motive for return, developed by Dustmann (1997), is the relatively high return to overseas human capital investments in the host country. In addition, exogenous factors can also explain the return of migrants e.g. sickness, war...etc. ${ }^{2}$ In this paper we do not study the determinants of return migration, but focus on its impact.

This paper contributes to our understanding of the effect of return migration and remittances on economic development in LDCs. There have been concerns that remittances and overseas savings are spent on current consumption or housing investment, and not invested in productive

\footnotetext{
${ }^{2}$ In this paper we do not model the duration of migration, but assume it is exogenous given the temporary nature of migration in the countries we are studying and the institutional barriers created by the importing Middle Eastern countries- though we test this assumption in Section 4.
} 
activities or small businesses- for example, see Taylor (1999) for a summary of that debate. This has led to analysis of the occupational choice of return migrants and in particular self-employment and entrepreneurship. Dustmann and Kirchkamp (2002) develop a model where migrants decide simultaneously about the optimal migration duration and their after return activities. They find that among Turkish returnees more than half are economically active and most of these engage in entrepreneurial activities. Mesnard (2000) models migration as a way to overcome credit constraints in the presence of capital markets imperfections. She finds that the majority of entrepreneurial projects started by Tunisian returnees were totally financed through overseas savings. Ilahi (1999) using cross-sectional data from Pakistan, finds that upon return, savings become a significant factor in the choice of self-employment over waged employment. McCormick and Wahba (2001) add a different insight by showing that savings matter more than human capital acquisition for the probability of entrepreneurship of illiterate Egyptian return migrants. However, for the educated returnees, both access to credit, through overseas savings, and human capital accumulation are significant determinants of entrepreneurship upon return. Unlike Ilahi (1999), Dustmann and Kirchkamp (2002) and Mesnard (2000) who focus on the choice of occupational activity upon return between self-employment and waged work, and McCormick and Wahba (2001) who use a wide definition of entrepreneurship 3 , in this paper, we focus our analysis on a particular type of entrepreneurship namely, investment in agricultural projects and non-farm small enterprises. In other words, we study return migrants who are business owners. In addition, unlike the above studies, we study the enterprises of both returnees and non-migrants.

Although, there is also a small descriptive literature on the use of remittances in small business formation, those studies are based on case studies of specific communities, for example, Durand and Massey (1992), Escobar and Martinez (1990), Portes and Guarnizo (1991) and Lopez and Seligson (1991). However, Woodruff and Zenteno (2001) is the first paper that uses census data- though only study urban areas- and examines the use of remittances- though not return migration- in the creation of micro enterprises. They study whether access to remittances is positively correlated with being an owner of a micro enterprise and examine the determinants of enterprise investments using migration rates in state. They find that remittances are responsible for

\footnotetext{
${ }^{3}$ In McCormick and Wahba (2001) entrepreneur refers to being either an employer, a self-employed, or someone with a business project in addition to their usual economic activity.
} 
$20 \%$ of the capital invested in micro-enterprises in urban Mexico. Furthermore, they find that most of the output growth associated with remittances by rural-origin migrants is located in urban areas. This suggests that the impact of remittances on investment is largely underestimated in most studies since they focus on the consequences of rural emigration and return for investment in rural areas. Our paper provides the first study using a survey with national coverage so that we are able to both include and distinguish between urban and rural areas when studying the impact of return migration and savings.

In section 2 we provide some information on international migration and the scale of remittances to Egypt, and a description of the data set on which our evidence is based. In Section 3 we examine the characteristics of return migrants by rural/urban origin. Section 4 discusses estimates of the probability of return migrants investing in projects/enterprises. In Section 5 we compare the businesses of returnees with those of non-migrants, and test whether return migration influences the nature and characteristics of enterprises. Finally, the main findings are summarised in the Conclusion.

\section{Background and Data}

After the oil boom of 1973, the Gulf oil -exporting countries found their development plans constrained by labour shortages, and embarked on importing large numbers of workers from neighbouring countries. At the peak, the Gulf states were importing $90 \%$ of their labour force. However, these countries have strict labour and migration laws, and all imported workers are on temporary contracts, resulting in a high imported labour turnover. Egypt has been exporting both educated and uneducated labour - with around $10 \%$ of the labour force working overseas at any point in time. Another important consequence has been huge in-flow of remittances to labour exporting countries such as Egypt, Jordan, Pakistan and Bangladesh, and it is estimated that official remittances from the Gulf countries have been around $\$ 70$ billion during the last three decades. Remittances to Egypt have been amongst the highest in the world peaking at $\$ 6.1$ billion in the early 1990s. Remittances have been a major source of foreign currency, not considerably different to the value of merchandise exports, and in the order of 5-11\% of GDP. Hence, given the temporary nature of migration and the magnitude of remittances, Egypt seems a good case study for the impact of return migration and remittances on development. 
This study uses data from the October 1988 special round of the Labour Force Sample Survey (LFSS), which was carried out by the Central Agency of Public Mobilisation and Statistics (CAPMAS) in Egypt. The 1988 LFSS is nationally representative and includes extensive data on basic demographics and employment characteristics, in addition, to several supplementary survey modules. One of which is on workers who are return migrants, where a migrant refers to someone who spent a minimum of six months overseas and has been overseas only for employment purposes. This return migration module describes the main characteristics of just over 1520 returnees in the labour market before and after migration, in addition to details on migration country of destination, migration duration, and savings whilst overseas.

In addition, the 1988 LFSS has a supplementary module on the nature of establishments where around 14000 workers were surveyed. This module being part of a household survey gathered information on all economic units and establishments regardless of firm size as is common in establishment surveys and thus captured all employment in the economy not just that that occurs within fixed establishments of a certain size. The economic unit module is extremely valuable in providing detailed picture of informal employment, compliance with labour regulations, and the legal status of firm. We use these data in section 5 to study the impact of return migration on different characteristics of enterprises.

\section{Characteristics of Return Migrants}

We begin by examining the characteristics of return migrants by urban/rural origin, given in Table 1. First, it is important to note that the share of our sample of return migrants originating in urban areas is almost equal to those from rural areas. Unsurprisingly, there are only small differences in certain of the observed characteristics of returnees with respect to their origin: almost all rural-origin returnees are males (97\%) compared to $92 \%$ of urban-origin returnees, while the average age of rural origin returnees is slightly less than that of urban origin returnees (38 years compared to 40 years).

However, other characteristics show larger rural-urban differences. Urban origin returnees tend to be more educated: only $16 \%$ of urban origin returnees have no formal education compared 
to $44 \%$ of the rural origin returnees. There also appear to be differences between the occupations whilst overseas of both groups. Almost $78 \%$ of rural-origin returnees were employed as agriculture or production workers, compared to $47 \%$ of urban-origin returnees. Around one-third of urbanorigin returnees were involved in technical, scientific and management occupations. Indeed, $47 \%$ of the urban-origin returnees reported to have acquired useful skills whilst overseas that were beneficial on their return, compared to only $25 \%$ among the rural-origin group. Rural-origin returnees stay on average less than 2 years overseas (1.9 years), whilst, those from urban-origin stay slightly longer (3.2 years). Another significant difference concerns the amount of overseas savings they accumulate. Obviously given that the urban sample is on average more educated, hence their overseas wages are higher and so are their savings. The average monthly savings of urban-origin returnees is twice as much as that of rural-origin ( $L E 777$ compared to $L E 366$ ). Given that urban origin migrants stay longer and save more, their average total savings is almost three times as much. In addition, since the proportion of returnees settling in urban areas is not very different from that which goes back to rural areas (Table 2A), the total amount of savings going back to urban areas is more than three times as much ( $L E 34$ mil compared to $L E 10$ mil). Thus, urban areas seem to benefit more than rural areas in attracting savings.

Amongst those that return to Egypt, the scale of international migration in the years prior to our 1988 Survey evidence reveal a simple inverted 'U' shape to the time pattern, with a peak in 1982, as given in Figure 1. Likewise the year of migrant's return also follows this shape, only with a peak in 1985, as given in Figure 2. This is consistent with the Survey evidence that the mean overseas spell length was around 2 years. In the period up to 1983 the migration was primarily from urban areas but this was sharply reversed in the post-1983 era. In many Western European countries during the $19^{\text {th }}$ century, the scale of overseas migration from rural areas was determined by the availability of jobs in the origin country urban areas, and this issue deserves exploration for major labour - exporting countries such as Egypt. Figures 1 and 2 together confirm that the decreasing urban share of out-migration from Egypt is subsequently reflected in the same change in the share of return migrants to urban and rural areas. This reflects at a macro level the strong evidence that migrants tend to return to their origin region. 
There is a concern that international migrants develop a taste for either 'big-city' life or the facilities of urban areas, and hence that returnees might settle back in more dense urban areas than in their origin. Table $2 \mathrm{~A}$ shows that $49.9 \%$ of migrants originate from urban areas and $48.5 \%$ return to urban areas. In addition, the share of returnees that lived in Greater Cairo before migration is (27.6\%) while on return that share is $26.6 \%$. Thus, overall the data do not support the hypothesis that return migrants have different preferences for cities than prior to migration. However, it is important to also examine the transitional probability of returnees by region to be able to examine flows rather than stocks. Overall Table 2B suggests that although up to $90 \%$ of all migrants go back to their region of origin, only $73 \%$ of Urban Upper Egypt residents do. Since looking at regions might still be masking movements within the region, a more disaggregate picture is provided. Around $8 \%$ of all returnees have changed either their geographical location of residence crossing either a governorate or urban/rural boundary. ${ }^{-1} 3.4 \%$ of rural origin returnees moved to urban areas, while $6.1 \%$ of urban origin returnees moved to rural areas by 1988. In addition, $3.4 \%$ of returnees have moved to a different governorate by the time of our survey. Overall, to sum up, the distribution of return migrants by both regional and rural/urban locations of residence was similar to that prior to migration, with very few migrants not returning to their former region.

Since we are interested in the human capital acquisition of return migrants and the impact of working overseas on their subsequent work and productivity on return, Table 3 displays the employment characteristics before and after migration by urban/rural residence. The proportion of employers in our sample rises from 10 to $19 \%$ between the pre-migration and post-return periods. Although the shares of employers increase in both urban and rural areas, the increase is striking in urban areas - four folds- compared to 50\% in rural areas. Although the proportion of waged urban workers falls, that is not the case in rural areas. Another difference between urban and rural workers, is that twice the proportion of urban workers have retired by 1988 compared to rural workers.

An examination of the public/private nature of work before and after migration suggests more striking changes. Whereas $45 \%$ of migrants had worked in public enterprise before migration

\footnotetext{
${ }^{4}$ There are 26 governorates and 6 regions in Egypt. There are 4 urban only governorates - Greater Cairo, Alexandria, Port Said, and Suez. All the other 22 governorates have both urban and rural areas.
} 
only $9 \%$ did so on return. In contrast, about one third of return migrants enter the private sector having previously not been employed there. However, those sectoral changes apply to both urban and rural residents. Another noticeable change occurred in our migrants' occupations. About 5\% more workers living in rural areas (an increase of around 50 percentage points) have technical and scientific jobs after return compared to pre-migration. Also, around 4\% more of workers dwelling in urban areas have managerial jobs after return compared to only $1 \%$ pre-migration. Moreover, less workers- both urban and rural- are employed as production workers post-migration. In other words, there seems to be some evidence that returnees have acquired human capital whilst overseas that has had an impact on their occupation and productivity. It is also important to note that there are $9 \%$ fewer rural workers engaged in agriculture. About $6 \%$ more work in trade in urban areas and $7 \%$ in services in rural areas. Nevertheless, overall the migrants returned to broadly similar industrial patterns of employment.

Uses of savings by migrants and their families have received a lot of attention in the literature. In our sample, and similar to many other studies- see for example, Adams (1991) - a large proportion of returnees invested in housing. Half of all rural-origin returnees, and $42 \%$ of urban-origin returnees, invested in housing. One third of all returnees report not having any savings: $36 \%$ of rural-origin and $30 \%$ of urban-origin returnees were unable to make any savings at all. However, what is of interest to us in this paper, is that $10 \%$ of returnees invested in economic projects as shown in Table 4. In the next coming section we will examine the characteristics of returnees who invested in business projects.

\section{The Investment Projects of Return Migrants: Who, Where and What?}

In this section we discuss the investment behaviour of return migrants, and begin by contrasting characteristics of returnees who invest in projects and businesses, with those who do not. We distinguish between two types of investment: agricultural projects and non-farm enterprises. We also separate those who invested in and established new non-farm enterprises after returning. We then construct an econometric model of the probability that a returning migrant invests into a project. ${ }^{\mathrm{S}}$ We estimate four different models to distinguish between different types of

\footnotetext{
${ }^{5}$ We limit our analysis to a sample of return migrants to avoid sample selection problems since we cannot correct for selectivity into migration. Data limitations do not allow us to correct for self-selection into migration( i.e. who migrates
} 
investments as follow: i) project/enterprise (agricultural project or non-farm enterprise), ii) agricultural project only, iii) non-farm enterprise only, and iv) new non-farm enterprise. In this section, we focus on returnees who are either employers or self-employed who have either invested in agricultural projects or invested in non-farm enterprises.

Table 5 gives the descriptive statistics of those return migrants who invest in agricultural projects, those who invest in non-farm enterprises and those who do not invest in any project. First, the average overseas total savings of returnees who invest in agricultural project is the lowest among all returnees. However, the importance of total savings is much greater for those returnees who invested in non-farm enterprises. We shall explore in our model below how far savings played a role in explaining the birth of new enterprises amongst the return migrants. Secondly, those who invested in non-farm enterprises have on average spent longer spells overseas of 4.3 years relative to a mean figure 2.4 years, of the non-investor returnees. Returnees who invest in agricultural projects are males, tend to be on average older than the rest of the sample and a big proportion of whom (64\%) are illiterates. A significant overall feature of returnees, who invest in non-farm enterprises, is that they are broadly drawn from all educational categories. However, they are on average more educated than those investing in agriculture. Finally, and not surprisingly, the majority of agricultural investors (96\%) live in rural areas. However, owners of non-farm enterprises tend to be predominantly urban dwellers. Thus, the descriptive statistics suggest an important geographical bias among returnees, which is that rural returnees tend to invest in agricultural projects, while urban returnees invest in non-farm enterprises.

Now, we construct a simple econometric model of the probability that a return migrant invests in a project/enterprise. Given that we are interested in examining the determinants of investing in an enterprise and whether overseas migration facilitates that process through two channels. First, overseas savings may provide individuals who otherwise are capital constrained with an opportunity to start an enterprise. As Evans and Jovanovic (1989) discuss, liquidity constraints tend to exclude those with insufficient capital to become entrepreneurs. Secondly,

and who does not) because we only have data on return migrants and on non-migrants, but no information on nonreturnees.

${ }^{6}$ We only study those two types of activities. Thus, those who have invested in an entrepreneurial activity, but have no fixed location for their establishments (for example, street vendors, construction workers...etc.) are not considered. 
overseas emigration may promote a more effective flow of information and knowledge and raise human capital of emigrants. Hence, we conjecture that the length of time spent overseas matters because of its implications on human capital acquisition, holding constant total savings.

We assume that the pay-off from the decision to start a project/enterprise is an unobserved variable $y^{*}$, and that

$$
y^{*}=\beta_{0}^{\prime} x+\gamma \ln S+\lambda \ln D+\mu
$$

where $S$ is accumulated overseas savings, $D$ is duration of overseas work experience in months, $x$ is a vector of individual and demographic characteristics of the returnee - such as urban/rural origin, age and educational background, and $\mu$ is normally distributed error term with mean zero and variance one. Since we do not observe $y^{*}$, only whether or not a returnee has invested in a project/ enterprise or not

$$
\begin{aligned}
& \mathrm{y}=1 \text { if } y^{*}>0, \\
& \mathrm{y}=0 \text { if } y^{*} \leq 0
\end{aligned}
$$

We estimate four different models using probit. First we study the probability that a returnee invests in either an agricultural project or in a non-farm enterprise. Secondly, we examine the probability that a returnee invests only in an agricultural project. Thirdly, we study the probability that a returnee invests in an economic project (a non-farm enterprise). Finally, we study the probability that a returnee establishes a new non-farm enterprise conditional upon not having an enterprise before migrating. The results of these four models are given in Table 6. In each model we have a included a range of demographic characteristics capturing the age of the returnee in 1988, the educational level achieved by the returnee, the urban or rural origin of the individual, and whether the individual was originally working in the government or public enterprise sector. In addition for two of the models where we include individuals who have had non-farm enterprises prior to overseas migration, we allow for this characteristic. The results of estimating probit models of these four specifications are shown in Table 6 where the marginal effects are reported.

First, we focus upon the two variables capturing overseas savings and time spent overseas. Given time spent overseas, we find that higher overseas savings generate a higher probability of a 
returnee investing in an agricultural project or non-farm enterprise, all else held equal. Thus our empirical evidence supports the hypothesis that access to credit through overseas migration and savings play an especially critical role in the decision to start economic ventures.

Another interesting issue is whether the length of overseas employment matters if we control for total savings. If the savings constraint is the only channel whereby overseas work can enhance establishing enterprises, then duration should not have a separate influence. We find that the effect of duration overseas given total savings on the probability of investing in a non-farm enterprise, whether new or old, is positive and significant. This suggests that learning overseas may matter for explaining entrepreneurship and that the influence of overseas work arises from channels other than the relaxation of a savings constraint. However, that relationship is negative and insignificant in the case of agricultural projects, i.e. overseas working experience has an insignificant impact on the probability of a returnee investing in an agricultural project.

To test the hypothesis that overseas migration provides emigrants with an opportunity to enhance their skills and human capital, the last column in Table 6, includes a dummy capturing whether the returnee reported that he has acquired useful skills whilst overseas. We find that there is a positive relationship between those who report having benefited from overseas work and the probability of investing in non-farm enterprise.

Examining the rest of the explanatory variables, the age of the returnee does not seem to have a significant influence on the probability that they start an enterprise, but have positive significant impact on investing in agriculture. In addition, there seems to be no selectivity by education when it comes to investing in enterprises: the educated are as likely to establish enterprises amongst return migrants than the uneducated. The role of public employment is an interesting one. Workers in the official government sector are perhaps unsurprisingly less likely to become investors but those in the government owned public enterprise sector are equally as likely to become investors as those in our reference group - private sector employees.

Given our interest in spatial inequality, it is important to explore how far amongst return migrants the probability of establishing businesses is affected by the region from which the 
individual originated. We find clear evidence that even after controlling for individual characteristics, savings and duration overseas, that region of origin makes a significant difference to the probability of a returnee investing in a project. Rural-origin returnees are much more likely than urban- origin ones to invest in agricultural projects. However, urban-origin returnees are more likely than their rural counterparts to invest in a non-farm enterprise though this is only significant at the $10 \%$ level.

\section{The Impact of Return Migration on the Structure of Enterprises}

In this section, we contrast the location and other characteristics of small enterprises owned by return migrants with those of other enterprises not owned by returnees. Thus, unlike the previous section, we do not limit our analysis to return migrants. We study owners (employers and self-employed) of non-farm small enterprises. We use a nationally representative sample of 1220 owners of enterprises conducted at the household level from the 1988 LFSS supplementary module on the economic unit. This module samples private, family owned, non-farm establishments; i.e. small enterprises. ${ }^{-}$Since the survey is household based, we have information on both regulated/registered and unregulated/unregistered enterprises. Thus we are able to study firms operating within the informal sector.

Table 7 displays the characteristics of the owners and their enterprises, distinguishing between return migrants and non-migrants. Our sample is made of 1220 non-farm small enterprises where 149 units are owned by return migrants; i.e. around $12 \%$ of enterprises are owned by returnees. First, we discuss the characteristics of the owners, then those of the firms. Returnees seem to be on average three years younger than non-migrant owners and mostly male. In addition, returnees tend to be more educated - $22 \%$ compared to $13 \%$ among non-migrants. Although $70 \%$ of non-migrants and $73 \%$ of returnees are urban dwellers, the proportion of returnees living in Greater Cairo is quite higher than that of non-migrants- $40 \%$ compared to $31 \%$.

We now examine the characteristics of small enterprises owned by returnees and stayers. First, considering the location of firms, a significant difference is that returnees tend to locate

\footnotetext{
${ }^{7}$ Those enterprises are small in the sense that that they are non-corporate and family owned. There is no restriction in sampling based on firm size, though the mean number of employees is less than 5 workers in around $85 \%$ of enterprises.
} 
almost half of their firms (47\%) in Greater Cairo compared to a third (32\%) by non-migrants. Secondly, it seems that there are differences in the industry or activity of both groups. The share of returnees' enterprises engaged in services activities is twice that of stayers. On the other hand, nonmigrants' enterprises tend to be concentrated in trade activities. The proportion of returnees' enterprises in manufacturing is about the same as that of non-migrants: $28 \%$ compared to $26 \%$.

A significant difference between returnees' and non-migrants' firms is the higher average estimated value of capital invested (in 1988 prices) by returnees. ${ }^{8}$ The average for returnees' firms is $L E 11,124$, while that for stayers is only $L E 8,638$. It is worth noting that around $2 \%$ of returnees and $1 \%$ of the stayers report zero as the estimated value of capital invested at the time of survey. Another apparent difference at returnees' firms is the higher average number of employees. Returnees create on average 1.5 more jobs per establishment than do stayers. Overall, return migrants are responsible for $15 \%$ of the capital invested in small enterprises and $15 \%$ of the associated employment generation.

Considering the geographical location of these jobs, Table 8 shows that $51 \%$ of jobs created by the returnees are located in Greater Cairo compared to $38 \%$ for other owners. In addition, only $13 \%$ of jobs created by returnees are located in rural areas, compared to $22 \%$ in the case of nonmigrants. Thus, our data suggest that there is a regional bias in firms and jobs location in favour of the capital city or the mega city. Furthermore, examining the region of residence of the owners and their chosen location for their enterprises, there is a clear indication amongst both groups, that more than half of the Upper Rural dwellers establish their firms in another region. However, amongst Upper Rural dwellers, the non-returnees tend to locate their firms in Urban Upper, while returnees favour Greater Cairo. Cornelius (1990) also finds that in Mexico, rural recipients of remittances often choose to invest in small businesses in urban areas, where both products and inputs markets are larger.

Table 7 also suggests that the majority of enterprises are small scale with less than 5 employees- $86 \%$ of returnees' and $85 \%$ of stayers'. However, the proportion of returnees who are

\footnotetext{
${ }^{8}$ Individuals are asked about the current estimated value of the capital invested in the enterprise at the time of the survey in 1988.
} 
not sole owners is $5 \%$ less than stayers; i.e. returnees tend to be more likely to invest in partnership, or have joint investment. It not surprising that on average the firms established by returnees, are more recent, although $31 \%$ of the returnees firms are established prior to emigration. In addition, to being interested in the geographical location of firms and jobs created, it is important to examine: (i) the nature of these firms whether they are operating as formal establishment and paying taxes thus raising government revenue or not and (ii) the nature of these jobs and whether they are “good" jobs or not. First, our sample suggests that around three-quarters of returnees' firms (76\%) have tax files, i.e. pay taxes, while only $67 \%$ do among non-migrants. Also, $80 \%$ of returnees' firms have a licence or registration, compared to $74 \%$ of stayers' enterprises. Secondly, it seems that returnees are as likely to employ "informal" workers who do not contribute to social security as non-migrants. However, returnees are more likely to provide 'good' jobs by paying their employees while on leave/holidays

We now examine whether return migrants' enterprises have significantly different characteristics. We do so by testing the following hypotheses:

1. Location of enterprises: There is a concern that international migrants develop a taste for either "big-city" life or the facilities of urban areas, and hence might locate their enterprises in more dense urban areas, especially in "big-cites", than in their origin. Thus, we test whether firms belonging to return migrants are more likely to be located in Greater Cairo.

2. Formality: Another hypothesis concerning the impact of return migration on the characteristics of enterprises is that return migrants are more likely to invest in formal enterprises (pay taxes and have a licence/registration) compared to non-migrants. Being overseas for a period might reduce the local knowledge, or the social capital, needed to be able to be successfully involved in an informal enterprise e.g. one with no licence.

3. Quality of Jobs: International migration to a higher wage country may provide the migrants with an environment in which there is higher proportion of higher quality jobs. Hence, we test whether return migrants create good jobs (e.g. jobs that offer paid leave). 
4. Activity/Industry: Given that our sample of Egyptian returnees have been migrants, primarily to Middle Eastern countries: Saudi Arabia, Jordan, Iraq, Kuwait and Libya, and not to highly industrialised countries, one would expect that the skills and information acquired by emigrants would be more useful in services than in manufacturing. Thus, we test whether firms owned by returnees tend to be in services.

5. Number of Jobs: Recent studies find that a big proportion of migrants that participate in the labour market after return are self-employed. ${ }^{[}$However, it important to examine whether return migrants create jobs and generate employment opportunities for others as well. Hence, we test whether enterprises owned by return migrants create as many jobs as other enterprises.

6. Value of capital invested: Banerjee and Newman (1993) show that only the wealthiest workers can invest in developing countries with credit market rationing. Credit market imperfections prevent low-income individuals from undertaking profitable investments. On the other hand, overseas savings allow the emigrant to be less credit constraint. Thus, we study whether given access to credit, returnees are more likely to invest more capital than non-migrants.

Our interest here is whether firms belonging to return migrants, controlling for the owner's individual characteristics, such as gender, age, education and urban/rural residence, are more likely to: (i) be located in Greater Cairo; (ii) be formal sector firm; (iii) create "good jobs"; (iv) be in manufacturing; (v) to be in services. Thus we estimate five equations using probit where the dependent variable in each case is the probability that the enterprise has a certain characteristic (e.g. being located in Greater Cairo; or being formal sector firm). We capture the effect of the owner being a return migrant by a variable which equals one, only if the owner is a return migrant, and control for the owners' other individual characteristics. However, we do not control for other characteristics of the enterprise as they are potentially endogenous.

In a similar framework we test the remaining two hypotheses: whether a returnee's firm has (i) an impact on the number of jobs created; and (ii) has a positive impact on the value of capital invested. We use OLS to estimate the first relationship, and tobit for the second relationship since

\footnotetext{
${ }^{9}$ For example, Ilahi (1999), Dustmann and Kirchkamp (2002) and Mesnard (2000).
} 
OLS would be inappropriate given that a small proportion of owners report zero as the estimated value of capital invested at the time of survey. Again we control for the owners' other exogenous individual characteristics. Table A1 gives a summary of the variable definitions.

Table 10 summarises the results of the above regressions, while Tables A2-A4 display the full estimates. First, our empirical findings support a positive and significant relationship between the location of enterprise and return migration. Being a returnee owner, compared to being a nonmigrant, increases the probability that an enterprise is located in Greater Cairo by almost $36 \%$. Thus, there is strong evidence that return migrants favour the big city location for their enterprise investment. However, return migration does not impact on the formality status of the enterprise. Returnees are as likely as stayers to establish formal sector firms. We have tried several definitions of formality. The one reported here in Table 10 refers to having a tax file. We have also used having a licence or registration, but have found similar results. Yet, enterprises owned by return migrants increases the likelihood by almost 30\% that jobs created are "good jobs". Although, return migrants are more likely than non-migrants, by almost $16 \%$, to invest in enterprises engaged in manufacturing, this relationship is not statistically significant. On the other hand, there is a strong and positive relationship between being a return owner of an enterprise and that enterprise being engaged in services.

Another important impact of return migration is on employment generation. An enterprise belonging to a return migrant is associated with $19 \%$ more jobs. Although we find a positive relationship, it is statistically insignificant. Finally, we find that return migration has a positive significant influence on the value of capital invested. Not surprising and supporting the hypothesis that overseas migration plays a critical role in reliving the credit constraint, the findings indicate that the value of capital invested is L£1417 - 17\% - more if the enterprise is owned by return migrant.

\section{Conclusion}

This paper explores entrepreneurship amongst return migrants, how their locations and business characteristics differ from other businesses, and the implications for geographical inequality. First, the paper describes the labour market activity of return migrants to Egypt, 
contrasting their situation with that prior to migration, and focussing on the characteristics and circumstances of returnees that engage in business ventures on return. We find that in the case of Egypt, migrants tend to return to their origin region. Although the proportion of returnees settling in urban areas is not very different from that which goes back to rural areas, the total amount of savings going back to urban areas is more than three times as much. Thus, urban areas benefit more than rural areas from international savings.

Secondly, in an econometric model of the probability of investing in enterprise amongst returnees, we find evidence supporting the hypotheses that overseas savings, and the duration of stay overseas, have positive separate effects on investing in a project/enterprise. The findings suggest how overseas migration, for even comparatively short spells, facilitates the accumulation of financial capital on a scale not otherwise possible, and the accumulation of new useful skills, that increase enterprise investment on return. We also find that region of origin makes a significant difference to the probability of a returnee investing in a project. Urban-origin returnees are more likely than their rural counterparts to invest in a non-farm enterprise.

Thirdly, we compare non-farm small enterprises owned by returnees to those owned by non-migrants. Our data suggest that there is a regional bias in the location of firms and jobs created by returnees compared to non-migrants, in favour of the capital city. We also find that there is a positive and significant relationship between the location of enterprises and return migration. Being a returnee owner, compared to being a non-migrant, increases the probability that an enterprise is located in Greater Cairo by almost 36\%. We do not find evidence that return migration influences the formality status of the enterprise, but it does impact on the quality of jobs favourably. In addition, we find weak evidence that return migration has a positive effect on employment generation. Finally, our empirical results suggest that return migration has a positive significant influence on the value of capital invested. Thus, overall the results support a positive impact of return migration on enterprise investment in urban areas. The economic contribution of return migrants in this sample supports the view that overseas work experience in a high wage country can play a useful role in the development process. 


\section{7. $\quad$ References}

Adams, Jr., Richard, 1989, "Workers remittances and inequality in rural Egypt", Economic Development and Cultural Change, 38(1): 45-71.

Adams, Jr., Richard, 1991, "The economic uses and impact of international remittances in rural Egypt”, Economic Development and Cultural Change, 39: 695-722.

Adams, Jr., Richard, 1992, "The impact of migration and remittances on inequality in rural Pakistan", Pakistan Development Review, 31: 1189-120.

Banerjee, A.V. and A.F. Newman, 1993, "Occupational choice and the process of development", Quarterly Journal of Economics, 105: 501-26.

Cornelius, W., 1990, "Labour migration to the United States: development outcomes and alternative in Mexican sending communities", Commission for the Study of International Migration and Co-operative Economic Development, Washington D.C.

Diatta, Marie Angelique and Ndiaga Mbow, 1999, "Releasing the development potential of return migration: the case of Senegal", International Migration, 37(1): 243-264.

Djajic, S., 1986, "International migration, remittances and welfare in a dependent economy", Journal of Development Economics, 21: 229-234.

Durand, Jorge, and Douglas S. Massey, 1991, "Mexican migration to the United States: A critical review", Latin American Research Review, 27: 3-42.

Dustmann, C. and O. Kirchkamp, 2002, "The optimal migration duration and activity choice after remigration", Journal of Development Economics, 67: 351-72.

Dustmann, C. 1997, "Return migration, savings and uncertainty", Journal of Development Economics, 52: 295-316.

Escobar, Agustin, and Maria de la O. Martinez, 1990, "Small-scale industry and international migration in Guadalajara, Mexico", Working Paper No.53, Commission for the Study of International Migration and Cooperative Economic Development, Washington D.C.

Evans, D. and B. Jovanovic, 1989, “An estimated model of entrepreneurial choice under liquidity constraints", Journal of Political Economy, 97: 808-827.

Galor, Oded and O. Stark, 1991, "The probability of return migration, migrants' work effort, and migrants performance", Journal of Development Economics, 35: 399-405.

Ilahi, Nadeem, 1999, "Return migration and occupational change", Review of Development Economics, 3: 170-86. 
Lopez, Jose Roberto and Mitchell Seligson, 1991, "Small business development in El Salvador: The Impact of Remittances", in Diaz-Briquets, Sergio and Sidney Weintraub, (eds.) Migration, Remittances and Small Business Development: Mexico and Caribbean Basin Countries, USA: Westveiw Press.

Lucas, Robert E.B., 1991, "Emigration to South Africa's mines", American Economic Review, 77: 313-330.

Lucas, Robert E.B. and Oded Stark, 1985, "Motivations to remit: evidence from Botswana", Journal of Political Economy, 93: 901-918.

McCormick, Barry, and Jackline Wahba, 2000, "Overseas employment and remittances to a dual Economy", The Economic Journal, 110: 509-34.

McCormick, Barry and Jackline Wahba, 2001, "Overseas work experience, savings and entrepreneurship amongst return migrants to LDCs", Scottish Journal of Political Economy, 48: 164-178.

Mesnard, Alice, 2001, “Temporary migration and capital market imperfections", University of Toulouse working paper.

Portes Alejandro and Luis Guarnizo, 1991, “ Tropical capitalists: US bound immigration and small enterprise development in the Dominican Republic", in Diaz-Briquets, Sergio and Sidney Weintraub, (eds.) Migration, Remittances and Small Business Development: Mexico and Caribbean Basin Countries, USA: Westveiw Press.

Rapoport, Hillel and Docquier, Frederic, 2002, "The economics of migrants' remittances", mimeo, forthcoming in Kolm, Gerard Varet and Mercier Ythier, (eds.) Handbook on the Economics of Reciprocity, Giving and Altruism, North Holland: Elsevier.

Rodriguez, Edgard and Susan Horton, 1995, "International return migration and remittances in the Philippines”, University of Toronto, Department of Economics Working Paper 95-01.

Stark, Oded, J. Edward Taylor, and Shlomo Yitzhaki, 1986, "Remittances and inequality", Economic Journal, 96: 722-740.

Taylor, J. Edward, 1992, "Remittances and inequality reconsidered: direct, indirect and intertemporal effects", Journal of Policy Modelling, 14(2): 187-208.

Taylor, J. Edward, 1999, "The new economics of labour migration and the role of remittances in the migration process", International Migration, 37(1): 63-88.

Thomas-Hope, Elizabeth, 1999, "Return migration to Jamaica and its development potential", International Migration, 37 (1): 183-205.

Woodruff, Christopher, and Rene Zenteno, 2001, "Remittances and microenterprises in Mexico", mimeo, University of California, San Diego. 
Table 1: Characteristics of Return Migrants by Origin

\begin{tabular}{|c|c|c|c|}
\hline & Urban Origin & Rural Origin & All Returnees \\
\hline \multicolumn{4}{|l|}{ Individual Characteristics } \\
\hline Male (\%) & 91.71 & 97.31 & 94.52 \\
\hline Mean of Age in 1988 & 40.35 & 38.02 & 38.84 \\
\hline Married in 1988 & 82.57 & 90.04 & 87.54 \\
\hline \multicolumn{4}{|l|}{ Education in 1988} \\
\hline Illiterate & 15.65 & 43.78 & 29.70 \\
\hline Read \& write & 14.79 & 21.31 & 18.06 \\
\hline Primary & 12.79 & 6.29 & 9.56 \\
\hline Preparatory & 23.83 & 16.53 & 20.10 \\
\hline Secondary & 5.07 & 3.46 & 4.25 \\
\hline University \& higher & 27.89 & 8.54 & 18.30 \\
\hline \multicolumn{4}{|l|}{ Occupation Overseas } \\
\hline Technical \& Scientific & 31.94 & 9.99 & 20.96 \\
\hline Management & 0.99 & 0 & 0.49 \\
\hline Clerical & 5.41 & 1.99 & 3.70 \\
\hline Sales & 4.64 & 3.66 & 4.16 \\
\hline Services & 9.84 & 6.86 & 8.35 \\
\hline Agriculture & 2.61 & 24.80 & 13.75 \\
\hline Production & 44.56 & 52.71 & 48.58 \\
\hline \multicolumn{4}{|l|}{ Skills acquired abroad } \\
\hline Beneficial to current job (\%) & 47.46 & 25.37 & 33.78 \\
\hline \multicolumn{4}{|l|}{ Overseas Duration and Savings } \\
\hline Years Spent Overseas (Mean) & 3.18 & 1.92 & 2.56 \\
\hline \multicolumn{4}{|l|}{ Average Monthly Overseas } \\
\hline Savings per migrant (LE) & 777 & 366 & 571 \\
\hline \multicolumn{3}{|l|}{ Total Overseas Savings per } & 29,331 \\
\hline \multicolumn{4}{|l|}{ Year of Overseas Migration } \\
\hline Pre 1974 & 15.31 & 6.66 & 10.97 \\
\hline 1974 - 1978 & 25.95 & 13.46 & 19.68 \\
\hline 1979 - 1982 & 35.72 & 35.86 & 35.79 \\
\hline 1983 - 1985 & 17.79 & 31.25 & 24.55 \\
\hline 1986 - 1988 & 5.23 & 12.77 & 9.02 \\
\hline \multicolumn{4}{|l|}{ Years Back } \\
\hline Less than 2 years & 14.41 & 21.44 & 17.94 \\
\hline $2-5$ years & 44.32 & 49.51 & 46.93 \\
\hline 6 years or more & 41.27 & 29.05 & 35.13 \\
\hline Sample Size : $N$ & 762 & 766 & 1528 \\
\hline$(\%)$ & 49.87 & 50.13 & 100 \\
\hline
\end{tabular}


Table 2A: Regional Origin \& Destination of Returnees

\begin{tabular}{lcc}
\hline \hline & Pre - Migration & In 1988 \\
\hline Urban & 49.87 & 48.52 \\
Rural & 50.13 & 51.48 \\
\hline Regions & & \\
Greater Cairo & 27.58 & 26.63 \\
Alexandria \& Canal Cities & 7.65 & 8.30 \\
Lower Urban & 10.61 & 10.52 \\
Upper Urban & 4.02 & 3.07 \\
Lower Rural & 25.59 & 25.33 \\
Upper Rural & 24.54 & 26.15 \\
\hline
\end{tabular}

Table 2 B: Transitional Probabilities of Returnees by Region ${ }^{1}$

\begin{tabular}{lccccccc}
\hline \multicolumn{1}{c}{ Pre - Migration } & \multicolumn{7}{c}{ In 1988 } \\
& $\begin{array}{l}\text { Greater } \\
\text { Cairo }\end{array}$ & $\begin{array}{l}\text { Alex. \& } \\
\text { Canal } \\
\text { Cities }\end{array}$ & $\begin{array}{l}\text { Lower } \\
\text { Urban }\end{array}$ & $\begin{array}{l}\text { Upper } \\
\text { Urban }\end{array}$ & $\begin{array}{l}\text { Lower } \\
\text { Rural }\end{array}$ & $\begin{array}{l}\text { Upper } \\
\text { Rural }\end{array}$ & TOTAL \\
& & & & & & \\
\hline Greater Cairo & $\mathbf{9 1 . 5 3}$ & 0.51 & 0.76 & 0.00 & 0.67 & 6.53 & 100.00 \\
Alexandria \& Canal Cities & 1.76 & $\mathbf{9 5 . 4 1}$ & 2.24 & 0.00 & 0.59 & 0.00 & 100.00 \\
Lower Urban & 2.29 & 1.86 & $\mathbf{9 1 . 8 4}$ & 0.00 & 4.01 & 0.00 & 100.00 \\
Upper Urban & 7.50 & 3.15 & 2.25 & $\mathbf{7 3 . 1 8}$ & 0.00 & 13.92 & 100.00 \\
Lower Rural & 1.21 & 1.20 & 1.17 & 0.00 & $\mathbf{9 6 . 4 2}$ & 0.00 & 100.00 \\
Upper Rural & 1.61 & 0.93 & 0.00 & 0.52 & 0.00 & $\mathbf{9 6 . 9 4}$ & 100.00 \\
\hline
\end{tabular}

NB: ${ }^{\text {Region of Residence }}$ 
Table 3: Work Characteristics of Returnees by Residence

\begin{tabular}{|c|c|c|c|c|c|c|}
\hline & \multicolumn{2}{|c|}{ Urban Residents } & \multicolumn{2}{|c|}{ Rural Residents } & \multicolumn{2}{|c|}{ All Returnees } \\
\hline & $\begin{array}{c}\text { Before } \\
\text { Migration } \\
\end{array}$ & $\begin{array}{l}\text { In } \\
1988 \\
\end{array}$ & $\begin{array}{c}\text { Before } \\
\text { Migration }\end{array}$ & $\begin{array}{c}\text { In } \\
1988 \\
\end{array}$ & $\begin{array}{c}\text { Before } \\
\text { Migration } \\
\end{array}$ & $\begin{array}{c}\text { In } \\
1988 \\
\end{array}$ \\
\hline \multicolumn{7}{|l|}{ Employment Status } \\
\hline Waged & 73.15 & 66.06 & 51.32 & 52.50 & 62.26 & 58.70 \\
\hline Employer & 2.68 & 10.40 & 17.58 & 26.25 & 10.10 & 18.51 \\
\hline Self Employed & 7.34 & 10.63 & 9.11 & 8.91 & 8.24 & 9.68 \\
\hline Unpaid family worker & 1.40 & 0.01 & 10.97 & 5.31 & 6.21 & 3.14 \\
\hline Unemployed & 1.98 & 6.36 & 2.07 & 3.58 & 2.03 & 4.92 \\
\hline $\begin{array}{l}\text { Unemployed-new entrant } \\
\text { to labour market }\end{array}$ & 5.32 & ---- & 4.26 & --- & 4.79 & --- \\
\hline Out of Labour Force & 8.14 & 6.21 & 4.70 & 3.29 & 6.39 & 4.70 \\
\hline \multicolumn{7}{|l|}{ Sector of Employment } \\
\hline Government & 35.29 & 33.71 & 17.02 & 25.39 & 25.91 & 29.32 \\
\hline Public Enterprises & 39.52 & 13.52 & 49.27 & 4.30 & 44.49 & 8.59 \\
\hline Private & 25.19 & 52.77 & 33.71 & 70.31 & 29.60 & 62.09 \\
\hline \multicolumn{7}{|l|}{ Occupation } \\
\hline Technical \& Scientific & 34.89 & 31.31 & 10.82 & 15.85 & 22.55 & 23.07 \\
\hline Management & 1.14 & 4.65 & 0 & 0.26 & 0.55 & 2.32 \\
\hline Clerical & 7.12 & 7.86 & 3.12 & 6.46 & 5.07 & 7.13 \\
\hline Sales & 6.03 & 10.44 & 2.08 & 3.44 & 4.01 & 6.72 \\
\hline Services & 5.15 & 7.56 & 4.83 & 5.91 & 4.56 & 6.69 \\
\hline Agriculture & 2.59 & 2.87 & 59.25 & 50.67 & 31.62 & 28.27 \\
\hline Production & 43.09 & 35.30 & 19.89 & 17.41 & 31.63 & 25.80 \\
\hline \multicolumn{7}{|l|}{ Industry } \\
\hline Agriculture & 3.79 & 3.93 & 60.03 & 50.93 & 32.61 & 28.90 \\
\hline Mining \& Manufacturing & 23.38 & 20.36 & 8.89 & 7.89 & 15.95 & 13.73 \\
\hline Electricity & 0.57 & 0.61 & 0.45 & 1.12 & 0.51 & 0.88 \\
\hline Construction & 15.40 & 11.34 & 7.69 & 5.16 & 11.45 & 8.06 \\
\hline Trade & 10.28 & 16.01 & 3.93 & 5.29 & 7.02 & 10.28 \\
\hline Transport & 8.57 & 9.31 & 3.80 & 6.70 & 6.93 & 7.93 \\
\hline Finance & 1.47 & 2.87 & 0.18 & 0.52 & 0.80 & 1.02 \\
\hline Services & 36.55 & 35.57 & 15.03 & 22.38 & 25.53 & 28.58 \\
\hline Sample Size & 762 & 741 & 766 & 787 & 1528 & 1528 \\
\hline
\end{tabular}


Table 4: Uses of Savings by Region of Origin ${ }^{1}(\%)$

\begin{tabular}{lccc}
\hline \hline & Urban & Rural & Total Sample \\
\hline & & & \\
Economic projects & 12.54 & 7.58 & 10.08 \\
Banks & 15.27 & 3.06 & 9.13 \\
Investment Companies & 3.76 & 0.96 & 2.35 \\
Gold \& jewellery & 3.87 & 3.07 & 3.47 \\
Housing & 42.06 & 50.10 & 46.10 \\
Securities \& shares & 0.06 & 0 & 0.03 \\
Others & 8.43 & 8.23 & 8.33 \\
& & & \\
No Savings & 30.43 & 35.59 & 33.00 \\
\hline \hline
\end{tabular}

${ }^{1}$ More than one response is allowed. 
Table 5: Descriptive Statistics of Returnees Who Invested in Projects

\begin{tabular}{|c|c|c|c|c|c|c|c|c|c|c|}
\hline & \multicolumn{2}{|c|}{$\begin{array}{l}\text { Project or } \\
\text { Enterprise }\end{array}$} & \multicolumn{2}{|c|}{$\begin{array}{c}\text { Agriculture } \\
\text { Project }\end{array}$} & \multicolumn{2}{|c|}{$\begin{array}{l}\text { Non-farm } \\
\text { Enterprise }\end{array}$} & \multicolumn{2}{|c|}{$\begin{array}{l}\text { New Non-farm } \\
\text { Enterprise }\end{array}$} & \multicolumn{2}{|c|}{$\begin{array}{c}\text { No } \\
\text { Project or } \\
\text { Enterprise }\end{array}$} \\
\hline & \multicolumn{5}{|c|}{ Characteristics of Overseas Stay } & Std. dev & mean & Std. dev & mean & Std. dev \\
\hline Average Monthly Savings & 720 & 1976.13 & 337 & 511.24 & 1225 & 2880.09 & 741 & 1480.53 & 529 & 945.49 \\
\hline Average Total Savings & 62,344 & 288,879 & 13,370 & 37,694 & 126,984 & 430,144 & 65,036 & 196,893 & 20,047 & 44,998 \\
\hline Months Spent overseas & 35.65 & 41.26 & 23.50 & 27.03 & 51.58 & 50.40 & 44.06 & 40.80 & 29.12 & 32.85 \\
\hline \multicolumn{11}{|l|}{ Years back } \\
\hline Less than 2 years, dummy=1 & 18.78 & 39.11 & 22.68 & 41.96 & 13.64 & 34.44 & 26.53 & 44.58 & 17.71 & 38.19 \\
\hline 2 - 5 years ago, dummy=1 & 44.82 & 49.81 & 47.76 & 50.10 & 40.91 & 49.33 & 39.93 & 49.46 & 47.52 & 49.96 \\
\hline More than 5 years, dummy=1 & 33.41 & 47.24 & 29.62 & 45.79 & 45.45 & 49.96 & 33.54 & 47.68 & 34.77 & 47.65 \\
\hline \multicolumn{11}{|l|}{ Individual Characteristics } \\
\hline Male & 99.79 & 4.62 & 1 & 0 & 99.51 & 7.04 & 98.40 & 12.66 & 93.04 & 25.46 \\
\hline Age & 42.49 & 10.99 & 43.64 & 11.19 & 40.97 & 10.56 & 40.10 & 9.96 & 38.26 & 11.21 \\
\hline Education: Illiterate & 45.81 & 49.90 & 64.12 & 48.10 & 21.64 & 41.32 & 19.66 & 40.14 & 25.26 & 43.47 \\
\hline Less Educated & 43.87 & 49.70 & 34.42 & 47.65 & 56.35 & 49.76 & 56.61 & 50.05 & 48.84 & 50.01 \\
\hline High Educated & 10.31 & 30.46 & 1.45 & 11.99 & 22.01 & 41.57 & 23.73 & 42.96 & 25.90 & 43.83 \\
\hline Useful Skills acquired abroad & 32.65 & 41.26 & 18.59 & 39.01 & 49.94 & 50.16 & 31.74 & 47.01 & 34.84 & 47.67 \\
\hline \multicolumn{11}{|c|}{ Employment Characteristics before migration } \\
\hline Government Sector & 7.05 & 25.64 & 2.48 & 15.60 & 13.08 & 33.83 & 12.94 & 33.90 & 26.79 & 44.31 \\
\hline Public Enterprise & 48.05 & 50.04 & 56.12 & 49.77 & 37.39 & 48.55 & 34.28 & 47.94 & 36.01 & 48.02 \\
\hline Pre-migration Establishment & 13.35 & 34.35 & ---- & ---- & 30.96 & 46.39 & & & & \\
\hline Region of Origin: Urban & 33.41 & 47.24 & 4.11 & 19.91 & 72.08 & 45.01 & 78.74 & 41.32 & 54.42 & 49.83 \\
\hline Sample Size: N (\%) & \multicolumn{2}{|c|}{$319(20.88 \%)$} & \multicolumn{2}{|c|}{$170(11.13 \%)$} & \multicolumn{2}{|c|}{$149(9.75 \%)$} & \multicolumn{2}{|c|}{$98(6.98 \%)$} & \multicolumn{2}{|c|}{$1209(20.88 \%)$} \\
\hline
\end{tabular}


Table 6: Determinants of Businesses Investment Amongst Returnees: Marginal Effects

\begin{tabular}{|c|c|c|c|c|c|}
\hline & $\begin{array}{c}\text { Projects/ } \\
\text { Enterprises }\end{array}$ & $\begin{array}{l}\text { Agriculture } \\
\text { Projects }\end{array}$ & $\begin{array}{c}\text { Non-farm } \\
\text { Enterprises }\end{array}$ & $\begin{array}{c}\text { New } \\
\text { Non-farm } \\
\text { Enterprises }\end{array}$ & $\begin{array}{c}\text { New } \\
\text { Non-farm } \\
\text { Enterprises }\end{array}$ \\
\hline \multicolumn{6}{|c|}{ Characteristics of Overseas Stay } \\
\hline Total Savings & $\begin{array}{l}0.043 \\
(2.48)\end{array}$ & $\begin{array}{l}0.027 \\
(1.84)\end{array}$ & $\begin{array}{l}0.007 \\
(2.82)\end{array}$ & $\begin{array}{l}0.007 \\
(2.61)\end{array}$ & $\begin{array}{l}0.004 \\
(2.38)\end{array}$ \\
\hline Months Spent overseas & $\begin{array}{l}0.002 \\
(3.78)\end{array}$ & $\begin{array}{l}-0.001 \\
(1.61)\end{array}$ & $\begin{array}{l}0.001 \\
(5.81)\end{array}$ & $\begin{array}{l}0.0005 \\
(6.27)\end{array}$ & $\begin{array}{c}0.0003 \\
(5.28)\end{array}$ \\
\hline Dummy $=1$, if returned & -0.001 & -0.044 & 0.013 & 0.023 & 0.018 \\
\hline 2 - 5 years ago & $(0.02)$ & $(1.05)$ & $(1.50)$ & $(2.23)$ & $(2.23)$ \\
\hline $\begin{array}{l}\text { Dummy }=1 \text {, if returned } \\
\text { more than } 5 \text { years }\end{array}$ & $\begin{array}{l}-0.008 \\
(0.16)\end{array}$ & $\begin{array}{l}-0.139 \\
(2.98)\end{array}$ & $\begin{array}{l}0.045 \\
(3.66)\end{array}$ & $\begin{array}{l}0.062 \\
(4.63)\end{array}$ & $\begin{array}{l}0.050 \\
(4.46)\end{array}$ \\
\hline \multicolumn{6}{|l|}{ Individual Characteristics } \\
\hline Male & $\begin{array}{l}0.307 \\
(2.62)\end{array}$ & ---- & $\begin{array}{l}0.029 \\
(2.21)\end{array}$ & ---- & --- \\
\hline Age & $\begin{array}{l}0.008 \\
(4.08)\end{array}$ & $\begin{array}{l}0.013 \\
(5.07)\end{array}$ & $\begin{array}{c}0.0001 \\
(0.36)\end{array}$ & $\begin{array}{c}-0.0003 \\
(1.28)\end{array}$ & $\begin{array}{c}-0.0002 \\
(1.13)\end{array}$ \\
\hline \multicolumn{6}{|l|}{ Education (ref.: illiterate) } \\
\hline Less Educated & $\begin{array}{l}-0.067 \\
(1.82)\end{array}$ & $\begin{array}{l}-0.109 \\
(2.71)\end{array}$ & $\begin{array}{l}0.014 \\
(1.42)\end{array}$ & $\begin{array}{l}0.007 \\
(0.99)\end{array}$ & $\begin{array}{l}0.004 \\
(0.73)\end{array}$ \\
\hline Highly Educated & $\begin{array}{l}-0.148 \\
(4.08)\end{array}$ & $\begin{array}{l}-0.258 \\
(3.71)\end{array}$ & $\begin{array}{l}0.002 \\
(0.16)\end{array}$ & $\begin{array}{l}-0.008 \\
(1.34)\end{array}$ & $\begin{array}{l}-0.008 \\
(1.76)\end{array}$ \\
\hline $\begin{array}{l}\text { Useful Skills acquired } \\
\text { abroad }\end{array}$ & ----- & ----- & ----- & ----- & $\begin{array}{l}0.030 \\
(3.50)\end{array}$ \\
\hline \multicolumn{6}{|c|}{ Employment Characteristics before migration (ref.: Private sector) } \\
\hline Government Sector & $\begin{array}{l}-0.261 \\
(6.56)\end{array}$ & $\begin{array}{l}-0.208 \\
(2.29)\end{array}$ & $\begin{array}{l}-0.261 \\
(4.13)\end{array}$ & $\begin{array}{l}-0.020 \\
(3.66)\end{array}$ & $\begin{array}{l}-0.015 \\
(3.77)\end{array}$ \\
\hline Public Enterprise Sector & $\begin{array}{l}0.006 \\
(0.18)\end{array}$ & $\begin{array}{l}0.062 \\
(1.53)\end{array}$ & $\begin{array}{l}-0.006 \\
(0.62)\end{array}$ & $\begin{array}{l}-0.002 \\
(0.29)\end{array}$ & $\begin{array}{l}-0.002 \\
(0.30)\end{array}$ \\
\hline $\begin{array}{l}\text { Pre-migration } \\
\text { Establishment }\end{array}$ & $\begin{array}{l}0.337 \\
(4.51)\end{array}$ & ----- & $\begin{array}{l}0.236 \\
(8.20)\end{array}$ & ----- & ----- \\
\hline \multicolumn{6}{|l|}{ Region of Origin } \\
\hline Urban & $\begin{array}{l}-0.211 \\
(7.61) \\
\end{array}$ & $\begin{array}{l}-0.337 \\
(9.65) \\
\end{array}$ & $\begin{array}{l}0.025 \\
(1.65) \\
\end{array}$ & $\begin{array}{l}0.020 \\
(1.66) \\
\end{array}$ & $\begin{array}{l}0.014 \\
(1.61) \\
\end{array}$ \\
\hline Base $^{1}$ & 0.394 & 0.370 & 0.031 & 0.024 & 0.017 \\
\hline Sample Size & 1523 & 1523 & 1523 & 1401 & 1401 \\
\hline Log Likelihood & -639.88 & -352.32 & -382.22 & -303.39 & -296.27 \\
\hline
\end{tabular}

Notes: Absolute values of t-statistics are in parentheses. Robust (Huber/White/sandwich) estimator of the variance was used in place of the conventional Maximum Likelihood Estimation variance estimator and observations were allowed to be not independent within cluster. Marginal effects show the increment in the probability and are calculated at the reference set of individual characteristics and sample means. ${ }^{1}$ The reference individual is male returnee with no education, from rural origin, working in the private sector prior to migration. 


\begin{tabular}{|c|c|c|c|}
\hline & "Returnees & "Non-Migrants & Total \\
\hline \multicolumn{4}{|l|}{ Location (\%) } \\
\hline Greater Cairo & 47.29 & 32.36 & 34.34 \\
\hline Alexandria \& Canal Cities & 14.20 & 12.92 & 13.08 \\
\hline Lower Urban & 16.93 & 23.52 & 22.65 \\
\hline Upper Urban & 4.03 & 8.35 & 7.78 \\
\hline Lower Rural & 11.38 & 15.09 & 14.60 \\
\hline Upper Rural & 6.17 & 7.76 & 7.55 \\
\hline URBAN & 82.45 & 77.01 & 77.73 \\
\hline RURAL & 17.55 & 22.81 & 22.12 \\
\hline \multicolumn{4}{|l|}{ Industry (\%) } \\
\hline Agriculture & 1.49 & 0.92 & 1.00 \\
\hline Mining \& Manufacturing & 27.51 & 26.41 & 26.56 \\
\hline Construction & 4.96 & 1.54 & 1.99 \\
\hline Trade & 42.11 & 57.13 & 55.15 \\
\hline Transport & 1.09 & 0.91 & 0.94 \\
\hline Finance & 4.70 & 3.80 & 3.92 \\
\hline Services & 18.14 & 9.17 & 10.36 \\
\hline \multicolumn{4}{|c|}{ Estimated Value of Capital Invested (LE) } \\
\hline 1. None & 2.29 & 0.80 & 1.00 \\
\hline 1. Less than 100 & 2.57 & 6.31 & 5.81 \\
\hline 2. $100-499$ & 5.58 & 11.29 & 10.54 \\
\hline 3. $500-999$ & 6.27 & 12.07 & 11.30 \\
\hline 4. $1000-4999$ & 25.29 & 23.55 & 23.78 \\
\hline $5.5000-9999$ & 21.71 & 18.63 & 19.04 \\
\hline 6. more than 10000 & 35.20 & 26.12 & 27.32 \\
\hline $\begin{array}{l}\text { Mean Estimated Value of } \\
\text { Capital Invested (LE) }\end{array}$ & 11124 & 8638 & 8966 \\
\hline \multicolumn{4}{|l|}{ Number of Employees } \\
\hline 1. Less than 5 & 86.36 & 84.56 & 84.80 \\
\hline $2.5-9$ & 7.34 & 9.07 & 8.84 \\
\hline 3. $10-19$ & 2.49 & 3.87 & 3.69 \\
\hline 4. 201.039 & 0.99 & 1.42 & 1.36 \\
\hline 5.50 or more & 1.95 & 0.14 & 0.38 \\
\hline Mean number of employees & 5.89 & 4.30 & 4.51 \\
\hline \multicolumn{4}{|l|}{ Ownership } \\
\hline Sole Owner & 70.72 & 76.39 & 75.64 \\
\hline \multicolumn{4}{|l|}{ Year Established } \\
\hline Pre 1952 & 4.02 & 8.42 & 7.84 \\
\hline 1952-1959 & 2.29 & 8.79 & 7.93 \\
\hline
\end{tabular}




\begin{tabular}{|c|c|c|c|}
\hline 1960-1969 & 6.85 & 16.11 & 14.88 \\
\hline 1970-1979 & 17.90 & 26.57 & 25.43 \\
\hline 1980-1988 & 62.56 & 38.48 & 43.81 \\
\hline Pre-migration Establishment & 30.96 & ---- & 30.96 \\
\hline \multicolumn{4}{|l|}{ Firm has tax file } \\
\hline Yes & 76.24 & 67.46 & 68.62 \\
\hline No & 15.82 & 23.38 & 22.38 \\
\hline \multicolumn{4}{|l|}{ Firm has registration/licence } \\
\hline Yes & 80.49 & 73.78 & 74.80 \\
\hline No & 14.35 & 16.08 & 15.85 \\
\hline Not required & 4.16 & 10.02 & 9.25 \\
\hline \multicolumn{4}{|l|}{$\begin{array}{l}\text { Workers contribute to social } \\
\text { security }\end{array}$} \\
\hline All & 14.75 & 12.66 & 12.94 \\
\hline None & 32.99 & 31.98 & 32.12 \\
\hline \multicolumn{4}{|l|}{ Firm pays workers paid leave } \\
\hline All & 18.14 & 10.53 & 11.54 \\
\hline Some & 6.94 & 6.10 & 6.21 \\
\hline None & 66.40 & 72.33 & 71.55 \\
\hline \multicolumn{4}{|c|}{ Individual Characteristics of Owners } \\
\hline Mean Age in 1988 & 40.97 & 43.56 & 43.22 \\
\hline Male (\%) & 99.51 & 83.92 & 85.98 \\
\hline \multicolumn{4}{|l|}{ Education (\%) } \\
\hline Illiterate & 21.64 & 36.33 & 34.38 \\
\hline Less Educated & 56.35 & 50.83 & 51.56 \\
\hline Highly Educated & 22.01 & 12.84 & 14.05 \\
\hline \multicolumn{4}{|l|}{ Region of Residence (\%) } \\
\hline Greater Cairo & 40.41 & 30.58 & 31.88 \\
\hline Alexandria \& Canal Cities & 14.48 & 12.82 & 13.04 \\
\hline Lower Urban & 15.44 & 20.14 & 19.52 \\
\hline Upper Urban & 2.70 & 6.84 & 6.29 \\
\hline Lower Rural & 12.59 & 18.16 & 17.42 \\
\hline Upper Rural & 14.38 & 11.46 & 11.84 \\
\hline URBAN & 73.03 & 70.38 & 70.74 \\
\hline RURAL & 26.97 & 29.62 & 29.26 \\
\hline Total Size & 1071 & 149 & 1220 \\
\hline$(\%)$ & 87.79 & 12.21 & 100 \\
\hline
\end{tabular}


Table 8: Number of Jobs Created by Region (\%)

\begin{tabular}{lcc}
\hline \hline & Returnees & Non-Migrants \\
\hline Greater Cairo & 50.79 & 38.14 \\
Alexandria \& Canal Cities & 11.06 & 11.61 \\
Lower Urban & 22.01 & 19.34 \\
Upper Urban & 2.71 & 8.72 \\
Lower Rural & 9.71 & 15.76 \\
Upper Rural & 3.72 & 6.43 \\
\hline & & \\
Urban & 86.57 & 77.81 \\
Rural & & \\
Total (\%) & 13.43 & 22.19 \\
Total number of jobs & 100.00 & 100.00 \\
\hline \hline
\end{tabular}


Table 9 : Residence of Business Owners and Location of Businesses

\begin{tabular}{|c|c|c|c|c|c|c|c|}
\hline \multirow[t]{3}{*}{ Residence } & \multicolumn{7}{|c|}{ Business Location } \\
\hline & \multicolumn{7}{|c|}{ Returnees } \\
\hline & $\begin{array}{l}\text { Greater } \\
\text { Cairo }\end{array}$ & $\begin{array}{l}\text { Alex. \& } \\
\text { Canal } \\
\text { Cities } \\
\end{array}$ & $\begin{array}{l}\text { Lower } \\
\text { Urban }\end{array}$ & $\begin{array}{l}\text { Upper } \\
\text { Urban }\end{array}$ & $\begin{array}{l}\text { Lower } \\
\text { Rural }\end{array}$ & $\begin{array}{l}\text { Upper } \\
\text { Rural }\end{array}$ & TOTAL \\
\hline Greater Cairo & 100.00 & 0.00 & 0.00 & 0.00 & 0.00 & 0.00 & 100.00 \\
\hline Alexandria \& Canal Cities & 0.00 & 94.81 & 5.19 & 0.00 & 0.00 & 0.00 & 100.00 \\
\hline Lower Urban & 0.00 & 3.02 & 45.68 & 0.00 & 51.30 & 0.00 & 100.00 \\
\hline Upper Urban & 0.00 & 0.00 & 0.00 & 78.43 & 0.00 & 21.57 & 100.00 \\
\hline Lower Rural & 0.00 & 0.00 & 72.53 & 0.00 & 27.47 & 0.00 & 100.00 \\
\hline \multirow[t]{3}{*}{ Upper Rural } & 47.80 & 0.93 & 0.00 & 13.34 & 0.00 & 38.86 & 100.00 \\
\hline & \multicolumn{7}{|c|}{ Non-Migrants } \\
\hline & $\begin{array}{l}\text { Greater } \\
\text { Cairo }\end{array}$ & $\begin{array}{l}\text { Alex. \& } \\
\text { Canal } \\
\text { Cities } \\
\end{array}$ & $\begin{array}{l}\text { Lower } \\
\text { Urban }\end{array}$ & $\begin{array}{l}\text { Upper } \\
\text { Urban }\end{array}$ & $\begin{array}{l}\text { Lower } \\
\text { Rural }\end{array}$ & $\begin{array}{l}\text { Upper } \\
\text { Rural }\end{array}$ & TOTAL \\
\hline Greater Cairo & 98.15 & 0.00 & 0.00 & 0.60 & 1.26 & 0.00 & 100.00 \\
\hline Alexandria \& Canal Cities & 0.00 & 100.00 & 0.00 & 0.00 & 0.00 & 0.00 & 100.00 \\
\hline Lower Urban & 0.35 & 0.35 & 60.33 & 0.00 & 38.96 & 0.00 & 100.00 \\
\hline Upper Urban & 0.00 & 0.00 & 0.0 & 57.24 & 0.00 & 42.76 & 100.00 \\
\hline Lower Rural & 0.00 & 0.00 & 62.37 & 0.00 & 37.63 & 0.00 & 100.00 \\
\hline Upper Rural & 19.65 & 0.00 & 0.00 & 37.58 & 0.00 & 42.78 & 100.00 \\
\hline
\end{tabular}


Table 10: Impact of Return Migration on Businesses

\begin{tabular}{lccc}
\hline \hline & \multicolumn{2}{c}{ Effect of Returnee's Business on } \\
\hline $\begin{array}{l}\text { Probability of } \\
\text { Business Located in } \\
\text { Greater Cairo }\end{array}$ & Coefficient & Marginal Effect & $(\%)$ \\
$\begin{array}{l}\text { Probability of } \\
\text { Formal Business }\end{array}$ & $0.355^{*}$ & $0.114^{*}$ & $35.8^{*}$ \\
$\begin{array}{l}\text { Probability of } \\
\text { Good jobs }\end{array}$ & -0.091 & -0.034 & -5.4 \\
$\begin{array}{l}\text { Probability of } \\
\text { Manufacturing Business }\end{array}$ & $0.263^{* *}$ & & $30.3 * *$ \\
Probability of \\
Services Business
\end{tabular}

* significant at 5\%. $* *$ significant at $10 \%$. 
Appendix

Table A1: Definition of Variables in Section 5

\section{Dependent Variables}

Located in Greater Cairo

Formal enterprise

Good jobs

Manufacturing enterprise

Services enterprise

Number of jobs

Value of $\mathrm{K}$ invested

Independent Variables

Returnee's enterprise

Male

Age

Age squared

\section{Education}

None

Less educated

High educated

Urban Residence
Dummy $=1$ if enterprise located in Greater Cairo, 0 otherwise

Dummy $=1$ if enterprise has tax file i.e. formal sector, 0 otherwise

Dummy $=1$ if, enterprise provides all employees with paid leave, 0 otherwise

Dummy $=1$, if enterprise is engaged in manufacturing activities, 0 otherwise

Dummy $=1$, if enterprise is engaged in services activities, 0 otherwise Number of jobs created by enterprise

Estimated value of capital invested in enterprise

Dummy $=1$ if enterprise is owned to a returnee

Dummy $=1$ if enterprise is owned by a male

Age in years of enterprise owner

Age squared

Dummy $=1$, if enterprise owner has no education

Dummy $=1$, if enterprise owner has less than secondary education

Dummy $=1$, if enterprise owner has secondary or university education

Dummy $=1$, if enterprise owner lives in urban areas 
Table A2: Impact of Return Migration on Enterprise 's Characteristics: Marginal Effects

\begin{tabular}{|c|c|c|c|}
\hline & $\begin{array}{c}\text { Probability of } \\
\text { Enterprise in Greater } \\
\text { Cairo }\end{array}$ & $\begin{array}{c}\text { Probability of } \\
\text { Formal Enterprise }\end{array}$ & $\begin{array}{l}\text { Probability of } \\
\text { Good jobs }\end{array}$ \\
\hline Returnee's business & $\begin{array}{l}0.114 \\
(2.33)\end{array}$ & $\begin{array}{l}-0.034 \\
(0.73)\end{array}$ & $\begin{array}{l}0.076 \\
(1.90)\end{array}$ \\
\hline Male & --- & $\begin{array}{l}0.375 \\
(8.85)\end{array}$ & $\begin{array}{l}0.074 \\
(1.00)\end{array}$ \\
\hline Age & $\begin{array}{l}0.001 \\
(0.12)\end{array}$ & $\begin{array}{l}0.029 \\
(4.69)\end{array}$ & $\begin{array}{l}0.008 \\
(1.08)\end{array}$ \\
\hline Age squared & $\begin{array}{c}0.00002 \\
(0.42)\end{array}$ & $\begin{array}{c}-0.0003 \\
(4.40)\end{array}$ & $\begin{array}{c}-0.0001 \\
(1.04)\end{array}$ \\
\hline \multicolumn{4}{|l|}{ Education } \\
\hline None & ----- & ---- & $\begin{array}{l}-0.120 \\
(2.84)\end{array}$ \\
\hline Less educated & $\begin{array}{l}0.085 \\
(2.39)\end{array}$ & $\begin{array}{l}0.131 \\
(4.83)\end{array}$ & --- \\
\hline High educated & $\begin{array}{l}0.176 \\
(1.73)\end{array}$ & $\begin{array}{l}0.228 \\
(3.21)\end{array}$ & ---- \\
\hline Urban Residence & ---- & $\begin{array}{l}0.234 \\
(4.27)\end{array}$ & $\begin{array}{l}0.159 \\
(3.16)\end{array}$ \\
\hline Base & 0.318 & 0.631 & 0.251 \\
\hline $\begin{array}{l}\text { Sample Size } \\
\text { Log Likelihood }\end{array}$ & $\begin{array}{c}1220 \\
-704.717\end{array}$ & $\begin{array}{c}1220 \\
-656.81\end{array}$ & $\begin{array}{c}1220 \\
-439.36\end{array}$ \\
\hline
\end{tabular}

Notes: Absolute values of t-statistics are in parentheses. Robust (Huber/White/sandwich) estimator of the variance was used in place of the conventional Maximum Likelihood Estimation variance estimator and observations were allowed to be not independent within cluster.

Marginal effects show the increment in the probability and are calculated at the reference set of individual characteristics and sample means. 
Table A3: Impact of Return Migration on Enterprise 's Activity: Marginal Effects

\begin{tabular}{lcc}
\hline \hline & $\begin{array}{c}\text { Probability of } \\
\text { Manufacturing enterprise }\end{array}$ & $\begin{array}{c}\text { Probability of } \\
\text { Services enterprise }\end{array}$ \\
\hline Returnee's business & 0.048 & 0.095 \\
Male & $(1.31)$ & $(1.89)$ \\
Age & -0.144 & 0.111 \\
Age squared & $(2.39)$ & $(2.13)$ \\
& -0.015 & -0.002 \\
Education & $(3.21)$ & $(0.25)$ \\
Less educated & 0.0001 & 0.00 \\
High educated & $(2.28)$ & $(0.06)$ \\
& & \\
Urban Residence & -0.029 & -0.002 \\
& $(1.27)$ & $(0.05)$ \\
Base & -0.172 & -0.095 \\
Sample Size & $(4.92)$ & $(1.63)$ \\
Log Likelihood & -0.115 & 0.105 \\
\hline \hline
\end{tabular}

Notes Absolute values of t-statistics are in parentheses. Robust (Huber/White/sandwich) estimator of the variance was used in place of the conventional Maximum Likelihood Estimation variance estimator and observations were allowed to be not independent within cluster.

Marginal effects show the increment in the probability and are calculated at the reference set of individual characteristics and sample means. 
Table A4: Impact of Return Migration on Number of Jobs and Capital Invested Number of Jobs : OLS Value of $\mathrm{K}$ invested: Tobit*

\begin{tabular}{lcc} 
Returnee's business & 0.894 & 1416.98 \\
Male & $(1.40)$ & $(1.70)$ \\
& 0.398 & 3263.49 \\
Age & $(2.13)$ & $(3.76)$ \\
& 0.007 & 12.26 \\
Education: None & $(0.70)$ & $(0.63)$ \\
& -1.073 & -4538.86 \\
Urban Residence & $(2.56)$ & $(7.52)$ \\
& 1.166 & 4821.93 \\
Constant & $(4.36)$ & $(7.00)$ \\
& 3.060 & 2825.42 \\
Sample Size & $(11.08)$ & $(2.51)$ \\
Adj. R2 & & 1220 \\
Log Likelihood & 1220 & ---- \\
\hline \hline
\end{tabular}

Notes: Absolute values of t-statistics are in parentheses. *22 observations out of 1220 are left censored. 
Fig 1: Estimates of Number of Migrants by Year of Migration \& Region of Origin

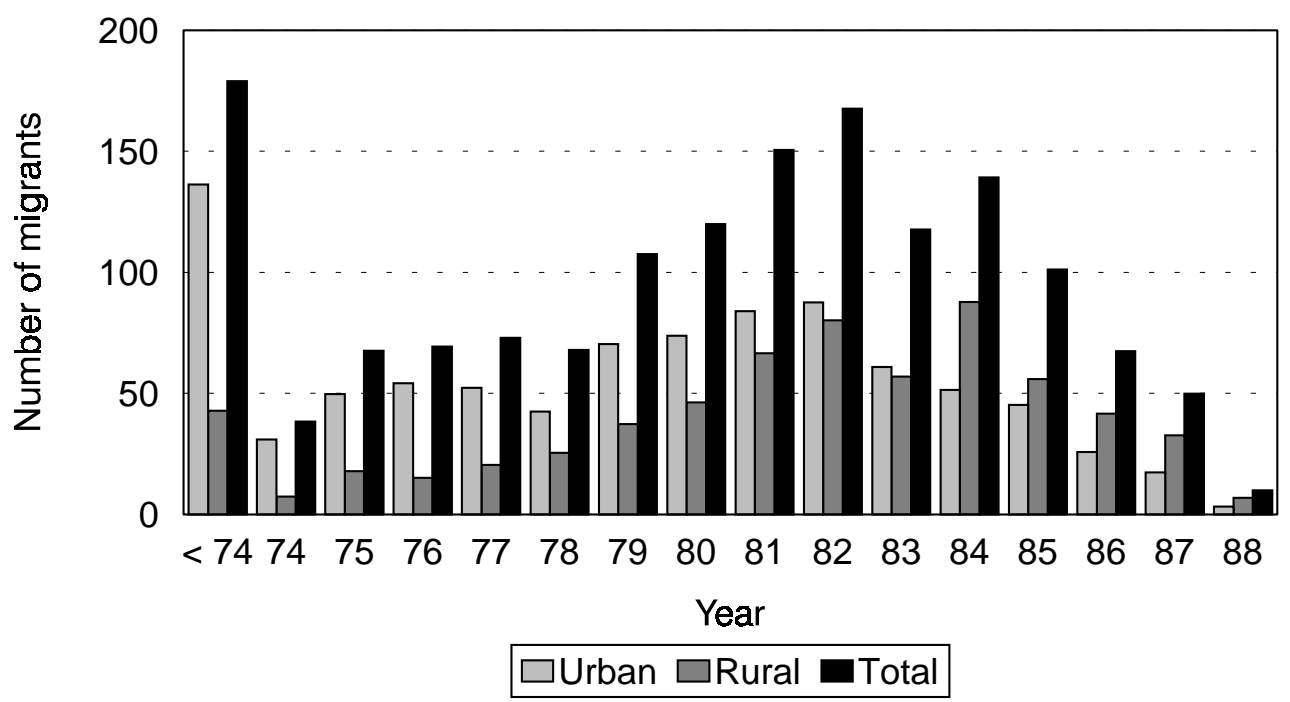

Fig 2: Estimates of Number of Return Migrants

By Year of Return Migration \& Region of Origin

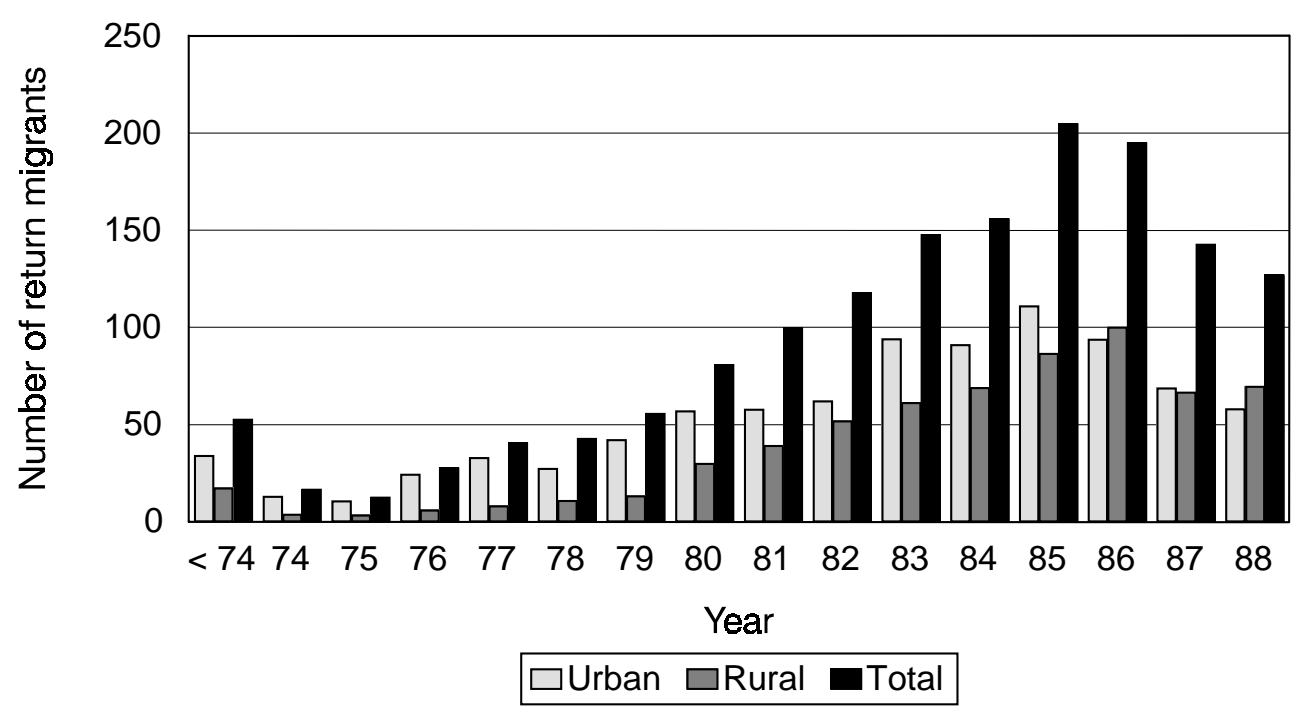

